\title{
PENGALAMAN PERAWAT UNIT PERAWATAN INTENSIF PSIKIATRI DALAM MERAWAT KLIEN DENGAN RISIKO BUNUH DIRI
}

\author{
Khusnul Aini $^{1 *}$, Mariyati ${ }^{2}$ \\ ${ }^{1}$ Program Studi S1 Keperawatan, Sekolah Tinggi Ilmu Kesehatan Kuningan, Jl. Lkr. Bayuning No.2, Kadugede, \\ Kabupaten Kuningan, Jawa Barat, Indonesia 45561 \\ ${ }^{2}$ Program Studi Ners, Sekolah Tinggi Ilmu Kesehatan Widya Husada Semarang, Jl. Subali Raya No.12, Krapyak, \\ Kec. Semarang Bar., Kota Semarang, Jawa Tengah, Indonesia 50146 \\ *khusnul.aini@gmail.com
}

\begin{abstract}
ABSTRAK
Pasien gangguan jiwa berat memiliki risiko bunuh diri sebesar 90\%. Membutuhkan kesiapan tenaga kesehatan jiwa, khususnya perawat yang memiliki waktu paling banyak dengan pasien, untuk memberikan manajemen asuhan yang tangkas, cermat dan professional di ruang akut. Penelitian ini bertujuan untuk mengetahui pengalaman perawat unit perawatan intensif psikiatri dalam memberikan asuhan keperawatan pada pasien gangguan jiwa dengan risiko bunuh diri. Metode penelitian yang dilakukan adalah kualitatif dengan pendekatan fenomenologi dengan indepth interview pada 5 orang perawat di ruang Unit Perawatan Intensif Psikiatri (UPIP) RSJ dr. Amino Gondohutomo Semarang, pada bulan November-Desember 2018. Hasil penelitian ini menguraikan tentang pengalaman perawat unit perawatan intensif psikiatri dalam merawat pasien dengan risiko bunuh diri. Penelitian ini menghasilkan 5 tema, yaitu: 1)Persepsi terhadap fenomena bunuh diri pada pasien gangguan jiwa, 2)Intervensi krisis pada pasien dengan risiko bunuh diri 3)Motivasi yang diberikan pada pasien dengan risiko bunuh diri, 4)Melibatkan keluarga dalam perawatan pasien dengan risiko bunuh diri, 5)Kendala dalam merawat pasien dengan risiko bunuh diri. Dari hasil penelitian ini diharapkan dapat meningkatkan pelayanan keperawatan pada pasien dengan risiko bunuh diri di ruang unit perawatan intensif psikiatri.
\end{abstract}

Kata kunci: perawat, unit perawatan intensif psikiatri, risiko bunuh diri

\section{THE EXPERIENCE OF PSYCHIATRIC INTENSIVE CARE UNIT NURSES FOR CARING CLIENTS WITH SUICIDE RISK}

\begin{abstract}
Severe mental patients have a suicide risk of 90\%. Requires readiness of mental health personnel, especially nurses who have the most time with patients, to provide competent, careful and professional care management in the acute space.This study aims to determine experience of psychiatric intensive care unit nurses in providing nursing care to mental patients with suicide risk.The research method used qualitative with a phenomenological approach by conducting in-depth interviews of 5 nurses in the Psychiatric Intensive Care Unit (UPIP) at dr. Amino Gondohutomo hospital on November until December 2018. The results of this study described the experience of psychiatric intensive care nurses in caring patients at risk of suicide.The number of participants in this study were 5 nurses in psychiatric intensive care unit with 2 until 8 years experiences.This study resulted in five themes: 1) The perception of the phenomenon of suicide in patients with mental disorders, 2) Crisis intervention in patients at risk of suicide 3) Motivation given to patients at risk of suicide, 4) Involve the family in the care of patients withsuicide risk, 5) Constraints in treating patients at risk of suicide. From the results of this study are expected to improve nursing care in patients at risk of suicide in the psychiatric intensive care unit.
\end{abstract}

Keywords: nurses, psychiatric intensive care unit, risk of suicide

\section{PENDAHULUAN}

Gangguan jiwa adalah keadaan disharmoni atau ketidakseimbangan dalam aspek kehidupan seseorang karena adanya tekanan atau distress baik yang disebabkan oleh individu, keluarga, teman atau relasi dan komunitas. Seseorang dengan masalah kesehatan jiwa sering dianggap sebagai orang yang tidak memiliki kekuatan untuk bertahan hidup secara utuh dan holistic (Fortaine, 2009). Sementara Stuart (2009) mendefinisikan gangguan jiwa adalah ketidakmampuan 
berespons secara positif terhadap konflik internal dan eksternal dalam kehidupan, lari dari masalah, frustasi, dan memiliki masalah dalam membangun hubungan interpersonal serta sosial.

Masalah kesehatan jiwa yang menimbulkan dampak paling serius baik bagi penderita, keluarga maupun masyarakat adalah gangguan jiwa berat. Lebih dari $90 \%$ korban bunuh diri memiliki masalah gangguan jiwa, sementara di negara berkembang $60-90 \%$ orang dengan gangguan jiwa berisiko melakukan bunuh diri. Seseorang dengan gangguan jiwa berat mempunyai keinginan untuk bunuh diri karena penderitaan yang dialami sangat panjang, merasa frustasi, harga diri rendah, distress spiritual, putus asa, tidak memiliki tujuan hidup serta kehilangan makna hidup (Fortaine, 2009).

Banyak definisi yang menjelaskan tentang perilaku bunuh diri, diantaranya Fox danHawton (2004) dalam Stevens, et all (2008) perilaku bunuh diri adalah suatu perilaku yang membahayakan diri sendiri yang berakibat fatal baik berupa percobaan bunuh diri atau tindakan bunuh diri itu sendiri. Fortaine (2009) menambahkan bahwa perilaku bunuh diri adalah gagasan atau keinginan dan tindakan bunuh diri atau mengakhiri hidupnya sendiri. Menurut Wood, Bellis, Mathieson dan Foster (2010) kelompok risiko tinggi bunuh diri termasuk gangguan kepribadian, gangguan makan, depresi dan cemas, kepribadian agresif, penggunaan alkohol dan obat terlarang, korban kekerasan fisik dan seksual, pengalaman hidup yang penuh stress, kemiskinan, serta riwayat keluarga dengan bunuh diri. Dari semua kelompok risiko tersebut yang terbesar adalah kelompok gangguan jiwa berat, dan bunuh diri adalah penyebab utama kematian penderita skizofrenia dengan jumlah terbesar terjadi pada usia produktif dan laki-laki (Gomez-Duran, Martin-Fumado, Hurtado-Ruiz, 2012).

Permasalah bunuh diri yang semakin meningkat tersebut membutuhkan suatu upaya pencegahan untuk mengurangi dan menekan terjadinya angka bunuh diri. Berbagai upaya pencegahan telah dilakukan yang dikelompokkan menjadi berbagai tipe program pencegahan dengan tiga setting utama, antara lain sekolah, komunitas dan unit - unit pelayanan kesehatan (Gould, 2003; Stevens, et al, 2008). Program yang dikembangkan adalah pendidikan dan program kesadaran kepada masyarakat dan kelompok professional, metode skrining pada kelompok risiko tinggi, treatment pada pasien gangguan jiwa, pembatasan mengakses segala sesuatu yang menyebabkan kematian, dan pelaporan melalui media tentang bunuh diri(Mann, J.J., Apter, A., Bertolote, J.,et al. (2010).

Berbagai penelitian telah dilakukan sebagai upaya pencegahan bunuh diri, namun ada beberapa keterbatasan yang perlu ditindaklanjuti antara lain kesulitan dalam melakukan generalisasi karena adanya berbagai faktor yang mempengaruhi efikasi strategi pencegahan bunuh diri seperti factor demografi (umur, usia, etnik atau suku bangsa, budaya, social ekonomi dan system sosial), sample yang sedikit, dan diskripsi prosedur intervensi yang kurang jelas (Scott \& Guo, 2012).

Perawat di ruang Unit Perawatan Intensif Psikiatri (UPIP) di RSJD dr. Amino Gondohutomo melaksanakan asuhan keperawatan pada pasien dengan masalah risiko bunuh diri sesuai dengan SOP yang ditetapkan oleh rumah sakit. Jumlah bed di ruang UPIP ada 18 bed dengan pasien yang dirawat dengan indikasi perilaku kekerasan dan risiko bunuh diri, namun angka kejadian kajian bunuh diri semakin meningkat dari tahun ke tahun. Dalam satu tahun terakhir pasien dengan risiko bunuh diri berkisar antara 30-50\%. Dengan tingginya masalah risiko bunuh diri yang ditemukan dalam setahun terakhir, membuat peneliti tertarik melakukan penelitian untuk mengetahui pengalaman perawat di ruang UPIP dalam merawat klien dengan risiko bunuh diri.

\section{METODE}

Penelitian ini menggunakan desain penelitian kualitatif dengan pendekatan fenomenologi untuk mendeskripsikan pengalaman perawat dalam merawat pasien dengan risiko bunuh diri. Pada penelitian melibatkan 5 perawat di ruang UPIP sebagai partisipan. Kemudian hasil wawancara dilakukan triangulasi data dengan kepala ruangan UPIP RSJD Dr. Amino Gondohutomo Semarang. Metode pengumpulan data dalam penelitian ini menggunakan teknik wawancara mendalam (indepth interview). Teknik ini dilakukan agar partisipan mampu mengungkapkan pengalamannya terkait fenomena yang pernah dialami dan yang diteliti yaitu informasi yang mendalam mengenai pengalaman perawat jiwa 
merawat pasien dengan risiko bunuh diri di ruang UPIP. Wawancara dilengkapi dengan field note untuk mengidentifikasi respon nonverbal dan situasi selama proses wawancara berlangsung. Serta melakukan triangulasi data dengan kepala ruangan UPIP.

Peneliti menggunakan panduan wawancara berupa pedoman wawancara mendalam yang disusun berdasarkan tujuan penelitian. Panduan ini terdiri dari kalimat pembukaan, kalimat kesepakatan kontrak, delapan pertanyaan pokok yang dikembangkan oleh peneliti dengan melakukan probing untuk mendapatkan informasi tentang fenomena pasien dengan risiko bunuh diri yang ditemukan perawat, standar pengamanan untuk pasien dengan risiko bunuh diri, serta upaya yang dilakukan perawat dalam mencegah upaya bunuh diri pasien yang di rawat di ruang UPIP, serta bagaimana melibatkan keluarga dalam perawatan. Semua pertanyaan mengacu pada tujuan penelitian dan diakhiri dengan kalimat penutup yang berisi tentang ucapan terimakasih dan kontrak untuk pertemuan selanjutnya ketika ada jawaban partisipan yang perlu divalidasi.

\section{HASIL}

Penelitian ini menghasilkan 5 tema, yaitu: 1) Penemuan kasus risiko bunuh diri pada pasien gangguan jiwa, 2) Perlindungan keselamatan pasien dengan risiko bunuh diri 3) Motivasi yang diberikan pada pasien dengan risiko bunuh diri, 4) Melibatkan keluarga dalam perawatan pasien dengan risiko bunuh diri, 5) Kendala dalam merawat pasien dengan risiko bunuh diri.Partisipan pertama adalah perawat yang berusia 42 tahun, pendidikan S1 Ners dan memiliki pengalaman lebih dari 7 tahun menjadi perawat di ruang UPIP dan sebelumnya telah berpengalaman di beberapa ruangan di RSJD dr. Amino Gondohutomo Semarang. Partisipan ke-2 adalah perawat laki-laki yang masih muda berusia 27 tahun dan baru memiliki pengalaman 2 tahun di ruang UPIP, hampir sama dengan partisipanke3 yang berusia 31 tahun dan sebelumnya juga pernah menjadi perawat di ruangan lain. Sementara partisipan ke-4 dan ke-5 adalah seorang perempuan yang masing-masing berusia 37 tahun dengan pengalaman 7 tahun dan 34 tahun dengan pengalaman 4 tahun. Kelima partisipan secara terbuka menceritan pengalaman mereka merawata pasien gangguan jiwa di ruang UPIP dengan masalah risiko bunuh diri.

\section{Tema 1 : Penemuan Kasus}

Tema penemuan kasus risiko bunuh diri berdasarkan penemuan 5 kategori yaitu 1)Peningkatan kasus, 2) Presentase kasus, 3) Kategori pasien, 4) Penyebab, 5) Percobaan bunuh diri yang pernah terjadi. Terdapat peningkatan kasus bunuh diri akhir-akhir ini yang masuk ke ruang UPIP, presentase kasus 30-50\% kasus yang ditemukan dengan risiko bunuh diri, kategori pasien sebagian besar karena depresi, keputusasaan, sebagian besar masih berusia muda atau produktif dan penyebabnya karena bullying, stigma masyarakat serta penolakan oleh keluarga maupun lingkungan.

Kategori pertama, partisipan menyampaikan bahwa akhir-akhir ini terjadi peningkatan kasus risiko bunuh diri pada pasien yang masuk di ruang UPIP. Kondisi ini dikuatkan oleh pernyataan dari partisipan 1,2,,4, dan 5 sebagai berikut :

"Akhir-akhir ini memang terjadi peningkatan kasus risiko bunuh diri Pada pasien yang masuk ruang UPIP” (P1)

"Kasus RBD akhir-akhir ini banyak sekali, bahkan hari ini ada 5 kasus" (P2)

"Ya..akhir-akhir ini terjadi peningkatan kasus risiko bunuh diri" (P4)

"Sangat meningkat kasusnya" (P5)

Kategori kedua, partisipan mengungkapkan tentang presentase kasus risiko bunuh diri yang masuk ke ruang UPIP, yang disampaikan oleh partisipan 1,2,3,4 dan 5 sebagai berikut:

"Sekitar sepertiga atau 35\% kasus dengan risiko bunuh diri" $(P 1)$

"Sekitar 30\% kasus dengan risiko bunh diri" (P2)

"Kurang lebih sekitar 30\% dari semua kasus yang masuk" (P3)

"Sekitar 30\% kasus dengan risiko bunuh diri" (P4)

"Hampir 50\% dengan risiko bunuh diri” (P5) 
Kategori ketiga, kategori pasien dengan risiko bunuh diri disampaikan oleh partisipan 1 , dan 5 sebagai berikut:

"Akhir-akhir ini banyak kasus pada usia muda bahkan anak-anak juga ada" (P1)

"Banyak kasus pada usia muda" (P5)

Kategori keempat adalah penyebab terjadinya masalah risiko bunuh diri pada pasien yang disampaikan oleh partisipan 1, 3 dan 5 sebagai berikut:

"Terutama karena bullying”(P1)

"Ada kasus pasien dengan RBD karena halusinasinya atau memang karena frustasi" (P3)

"ada yang sebelumnya RPK masuklagi dengan risiko bunuh diri" (P5)

Kategori kelima percobaan bunuh diri yang pernah terjadi selama di rawat di ruang UPIP berdasarkan penyataan yang disampaikan oleh partisipan 1, 3, dan 4 sebagai berikut:

"...membenturkan kepala, menggores nadi" (P1)

" Pasien gelisah, membenturkan kepala, menyayat tangan, colok stop kontak" (P3)

"Ada setahun yang lalu pasien gantung diri menggunakan sprei dibawah tempat tidur" (P4)

\section{Tema ke-2 : Perlindungan Keselamatan Pasien}

Tema perlindungan keselamatan pasien dengan risiko bunuh diri berdasarkan 4 kategori yang ditemukan yaitu 1) Pengkajian, 2) Pengawasan, 3) Modifikasi lingkungan dan 4) Penempatan ruangan untuk pasien dengan risiko bunuh diri.

Kategori pertama tentang pengkajian, bahwa upaya pengkajian yang dilakukan disampaikan oleh partisipan 1,2,3,4 dan 5 sebagai berikut:

"Assesment sudah dilakukan dari IGD, dan ada pengkajian khusus untuk kasus risiko bunuh diri" $(P 1)$

"Dari IGD sudah dilakukan pengkajian, dan dinyatakan pasien dengan risiko bunuh diri" (P2)

"Pengkajian khusus risiko bunuh diri sudah dilakukan sejak dari IGD”(P3)

"Assesment dilakukan oleh dokter jaga di IGD” (P4)
"Pengkajian dilakukan di IGD, dan di ruangan tinggal menindaklanjuti”(P5)

Setelah dilakukan pengkajian faktor risiko dan faktor proteksi yang ada pada pasien lalu dilakukan penilaian risiko bunuh diri yang dikategorikan menjadi risiko rendah, sedang dan tinggi.

Kategori kedua pengawasan, berdasarkan pernyataan yang disampaikan oleh partisipan $1,2,3,4$ dan 5 .

"Sesuai SOP rata-rata pengawasan ketat dilaukan $3 \times 24$ jam, atau sesuai dengan kondisi pasien" $(P 1)$

"Pengawasan yang lebih ketat" (P2)

"Pemantauuan harus lebih ketat untuk keselamatan pasien” (P3)

"Melakukan perbaikan pada pengawasan pasien” (P4)

"Yang utama adalah pengawasan untuk keselamatan pasien" (P5)

Kategori ketiga tentang modifikasi lingkungan yang disampaikan oleh partisipan 1, 2, 3, 4 dan 5 sebagai berikut:

"Sebaiknya ruangan tidak ada stop kontak, bed tanpa sprei, dan ruangan harus dibebaskan dari barang-barang yang berbahaya" (Pl)

"Ruangan harus dibebaskan dari barangbarang yang berbahaya, bed tanpa bed tanpa sprei kadang diletakkan di bawah" (P2)

“...bed tanpa sprei” (P3)

"Membebaskan ruangan dari benda-benda berbahaya yang bisa digunakan untuk bunuh diri, bahkan bednya pun tanpa sprei" (P4)

"Membebaskan ruangan dari benda-benda yang berbahaya buat pasien dan bahkan bednya tanpa sprei” (P5)

Kategori keempat penempatan ruangan berdasarkan informasi yang diberikan oleh partisipan 1, 2, 3, 4 dan 5 sebagai berikut:

"....menempatkan pasien di ruangan yang dekat nurse station" (P1)

“...ruangan khusus tidak ada, hanya di dekat nurse station” (P2)

“..ditempatkan di dekat nurse station” (P3) 
“...kamar pasien dekat nurse station untuk memudahkan pengawasan (P4)

“...pasien ditempatkan di dekat nurse station untuk memudahkan pengawasan” (P5)

\section{Tema ketiga : Motivasi yang Diberikan Perawat}

Kategori pertama mendengarkan pasien berdasarkan pernyataan yang disampaikan oleh partisipan 2 dan 4 sebagai berikut:

“..perlu pendekatan khusus untuk pasien mau terbuka pada perawat” (P2)

“...kami fasilitasi pasien untuk bercerita masalahnya" (P4)

Kategori kedua memberikan semangat berdasarkan pernyataan yang diberikan oleh partisipan P3, P4, dan P5 sebagai berikut:

" Jika pasien sudah nyaman dengan perawat baru diberikan motivasi” (P3)

"Sering diberikan motivasi dan perhatian khusus" (P4)

"Memberikan motivasi terus menerus pada pasien” (P5)

Kategori ketiga pendekatan spiritual berdasarkan pernyataan yang disampaikan oleh partisipan ke-4 sebagai berikut:

"Memotivasi pasien untuk sholat dan ngaji supaya ide bunuh diri tidak muncul" (P4

Kategori keempat menggali aspek positif yang dimiliki pasien berdasarkan pernyataan yang disampaikan oleh partisipan kelima sebagai berikut:

"Menggali aspek positif yang dimiliki pasien dan memberikan semangat hidup" (P5)

Tema keempat :Upaya Melibatkan Keluarga dalam Perawatan

Tema melibatkan keluarga dalam perawatan berdasarkan 2 kategori yang didapatkan yaitu edukasi pada keluarga dan melibatkan keluarga dalam pengawasan.

Kategori edukasi pada keluarga disampaikan oleh partisipan 1 dan 4 sebagai berikut:

"Keluarga sudah diajarkan cara merawat pasien dan melakukan pengawasan”(P1)

"Edukasi terhadap keluarga dari awal pasien masuk sudah dilakukan" (P4)
Kategori melibatkan keluarga dalam pengawasan selama dirawat di ruang UPIP disampaikan oleh partisipan 1, 2, 3, dan 4 sebagai berikut:

"Keluarga tinggal di ruangan bersama pasien sampai fase akut terlewati" (P1)

"Keluarga tinggal satu ruangan dengan pasien untuk mengawasi” (P2)

"Melibatkan keluarga dalam pengawasan" (P3)

“...melibatkan keluarga dalam pengawasan" (P4)

\section{Tema Kelima : Kendala yang Dirasakan Perawat}

Partisipan menyampaikan bahwa melibatkan keluarga dalam perawatan selama pasien di rawat di ruang UPIP, sangat membantu sekali. Karena pasien dengan risiko bunuh diri bisa melakukan percobaan bunuh diri jika perawat terlena sedikit saja, sehingga keterlibatan keluarga merupakan hal yang sangat penting. Tema kendala dalam merawat pasien dengan risiko bunuh diri didapatkan dari penemuan 5 kategori yaitu 1) Pasien sangat tertutup, 2) Kesulitan menggali ide bunuh diri yang masih ada, 3) Membutuhkan pengawasan yang ekstra ketat, 4) Keluarga kurang kooperatif dan 5) Percobaan bunuh diri berulang.

Kategori pertama pasien sangat tertutup sehingga menyulitkan perawat dalam membina hubungan saling percaya dengan pasien yang disampaikan oleh partisipan 2, dan 3 sebagai berikut:

"Seringkali pasien merasa canggung dan susah terbuka bercerita masalahnya pada perawat" $(P 2)$

"Rata-rata pasien sangat tertutup untuk menceritakan masalahnya” (P3)

Kategori kedua perawat kesulitan menggali ide bunuh diri yang masih ada, disampaikan oleh partisipan 2 dan 3 sebagai berikut:

"Pasien menghindar ketika ditanya terkait ide bunuh dirinya" $(P 2)$

"Pasien sangat tertutup sehingga sulit untuk menggali ide bunuh diri" (P3) 
Kategori ketiga dalam merawat pasien dengan risiko bunuh diri membutuhkan pengawasan yang ekstra ketat dibandingkan kasus lainnya, disampaikan oleh partisipan 1, 3 dan 5 sebagai berikut:

"Pasien dengan risiko bunuh dirimemang membutuhkan perawatan yang intensif" (P1)

“...pemantauan harus lebih ketat untuk keselamatan pasien” (P3)

“...pengawasan harus lebih ketat pada pasien dengan risiko bunuh diri”(P5)

Kategori keempat keluarga kurang kooperatif ketika dilibatkan dalam perawatan di ruang UPIP, sehingga menambah beban kerja perawat dalam pengawasan pasien dengan risiko bunuh diri disampaikan oleh partisipan 5 sebagai berikut:

"Pada pasien yang sering masuk karena kasus percobaan bunuh diri, keluarga menolak menunggui dengan berbagai alasan" (P5

Kategori kelima percobaan bunuh diri seringkali terulang lagi, disampaikan oleh partisipan 1, 2, 3, 4 dan 5 sebagai berikut:

"Kami memiliki keterbatasan, sehingga percobaan bunuh diri sering terulang lagi" (P1)

“...pasien gelisah lagi, bikin keributan, dan melakukan percobaan bunuh di ruang lain” (P2)

" Melakukan percobaan bunuh diri lagi sehingga kembali ke ruang UPIP” (P3)

"Biasanya di ruang lain mengancam bunuh diri sehingga kembali ke Ruang UPIP lagi”" (P4)

"Pasien gelisah dan mengancam untuk bunuh diri” (P5)

\section{PEMBAHASAN}

Semua partisipan pada penelitian ini adalah 5 perawat di ruang Unit Perawatan Intensif Psikiatri (UPIP) yang memiliki pengalaman antara 2 tahun sampai 7 tahun bekerja di ruang UPIP. Semua partisipan menyatakan bahwa akhir-akhir terjadi peningkatan kasus pasien yang masuk ruang UPIP sekitar 30-50\% dengan masalah risiko bunuh diri. Bahkan banyak terjadi pada usia yang lebih muda baik remaja maupun usia produktif. Dan rata-rata pelaku bunuh diri ada di rentang usia 15-29 tahun, bunuh diri merupakan penyebab kematian nomor dua di dunia. Berdasarkan data WHO tahun 2012 di Indonesia rata-rata bunuh diri pada laki-laki 3,7 per 100.000 penduduk dan 4,9 perempuan per 100.000 penduduk melakukan bunuh diri (Fleischmann, 2016). Penyebab bunuh diri sangat bervariasi mulai dari bullying, stigma masyarakat pada pasien dengan gangguan jiwa, penolakan oleh keluarga dan lingkungan dan masih banyak kasus lainnya seperti yang disampaikan oleh partisipan P1, P3 dan P5. Menurut Stuart (2016) faktor predisiposisi kejadian bunuh diri ada beberapa penyebab yang melatarbelakangi perilaku bunuh diri, antara lain : 1) Trauma interpersonal, 2) Trauma masa kecil, 3) Riwayat korban kekerasan, 4) Ketidakmampuan mengkomunikasikan kebutuhan, 5) Depresi, 6) Depersonalisasi, 7) Emosi yang fluktuatif dan 8) Skizofrenia.

Dalam penelitian ini didapatkan temuan bahwa pasien dengan isyarat, ancaman serta percobaan bunuh diri, berdasarkan hasil pengkajian yang dilakukan di ruang IGD psikiatri. Pasien dengan riwayat percobaan bunuh diri mendapatkan kategori risiko tinggi bunuh diri, karena lebih berisiko untuk melakukan percobaan bunuh diri kembali. Sebagian besar pasien dengan depresi, namun ada juga pasien yang melakukan percobaan bunuh diri karena perintah dari halusinasinya.

Perlindungan keselamatan pada pasien dengan risiko bunuh diri merupakan hal utama. Dibutuhkan prosedur yang ketat untuk bisa memberikan perlindungan yang optimal untuk pasien. Hal ini disampaikan oleh kelima partisipan yang menyampaikan bahwa di ruang UPIP sudah ada SOP untuk penanganan pasien dengan risiko bunuh diri. Prinsipnya adalah mengamankan pasien secara fisik dari bendabenda yang bernahaya yang bisa digunakan untuk bunuh diri, mengkondisikan ruangan yang aman bahkan bed yang digunakan juga tanpa spresi, karena ada kejadian sekitar setahun yang lalu ada pasien yang bunuh diri di bawah tempat tidur dengan menggunakan sprei.

Stuart (2016) menyampaikan bahwa orang yang paling berisiko bunuh diri adalah orang yang memiliki metode yang sangat mematikan untuk bunuh diri, rencana bunuh diri yang spesifik, dan tersedianya alat yang berbahaya untuk bunuh diri. Wasserman D (2016) 
menyatakan bahwa 9\%-25\% adalah kasus percobaan bunuh diri . Beberapa kasus bunuh diri yang terjadi memiliki karakteristik yang berbeda, dan perilaku bunuh diri meruupakapakan sebuah proses yang dinamis. Proses bunuh diri merupakan model stress yang sangat rentan, dan faktor yang berpengaruh antara lain: 1) Pemikiran dari pelaku bunuh diri, 2) Peranan faktor lingkungan, 3) Stress sangat berpengaruh terhadap risiko bunuh diri, 4) Bagaiamana orang lain atau lingkungan sosial dan budaya memberikan dukungan, 5) Tergantung seberapa faktor risiko dan protektif yang dimiliki.

Motivasi yang diberikan oleh perawat UPIP pada pasien dengan risiko bunuh diri lain: 1) Mendengarkan keluhan pasien adalah hal yang sangat penting dilakukan untuk mengetahui apa yang dirasakan oleh pasien sehingga memiliki pemikiran untuk mati. Hal ini disampaikan oleh partisipan P2 dan P4. 2) Memberikan semangat pada pasien untuk mendapatkan semangat hidup kembali dan bisa menemukan arti dalam kehidupan. 3) Memberikan kenyamanan pada pasien dan memberikan motivasi secara terus menerus. Hal ini sesuai dengan yang disampaikan oleh P3, P4 dan P5. 4)

Pendekatan spiritual juga perlu diberikan untuk pasien, yang biasa dilakukan adalah memotivasi pasien untuk mengaji dan sholat, yang bertujuan untuk mendapatkan ketenangan dan menemukan makna hidup kembali. Dukungan spiritual disampaikan oleh partisipan P4. 5) Menggali aspek positif yang dimiliki pasien, Perawat juga menggali aspek positif yang masih dimiliki oleh pasien. Sebagian besar pasien dengan risiko bunuh diri dengan depresi yang merasakan hidupnya sudah tidak berarti karena tidak ada lagi yang bisa dibanggakan.

Keluarga perlu dilibatkan dalam perawatan pasien dengan risiko bunuh diri, upaya melibatkan kelurga meliputi: 1) Edukasi yang diberikan oleh perawat kepada keluarga tentang perawatan pasien baik selama perawatan, maupun ketika pasien pulang ke rumah. Edukasi dilakukan sejak pasien masuk ruang UPIP. Hal ini disampaikan oleh partisipan P1 dan P4. 2) Melibatkan keluarga dalam pengawasan untuk keselamatan pasien disampaikan oleh P1, P2, P3 dan P4.
Stuart (2016) menyatakan bahwa prioritas tertinggi kegiatan keperawatan pada klien adalah melindungi mereka dari bahaya mencederai diri lebih lanjut dan melakukan bunuh diri. Keluarga adalah orang terdekat bagi klien baik secara fisik maupun secara emosional, sehingga diharapkan mampu memberikan kenyamanan serta support system yang dibutuhkan oleh pasien.

Perawat di ruang UPIP memiliki kendalakendala dalam merawat pasien dengan risiko bunuh diri, antara lain: 1) Pasien sangat tertutup, sehingga tidak mudah menggali apa yang dirasakan pasien saat ini. Seringkali pasien merasa canggung dan malu menyampaikan apa yang rasakan. 2) Kesulitan menggali ide bunuh diri yang masih ada pada pasien. Kondisi pasien yang tertutup juga menyulitkan perawat dalam menggali ide bunuh diri yang masih ada. 3) Pengawasan yang ekstra ketat, pasien dengan risiko bunuh diri membutuhkan pengawasan yang ekstra ketat dibandingkan dengan pasien lain, sehingga perawat harus terus waspada dan memantau pasien setiap saat. 4) Keluarga kurang kooperatif dalam perawatan pasien dengan risiko bunuh diri, ada beberapa keluarga yang menolak dalam perawatan pasien dengan risiko bunuh diri di ruang UPIP. Karena secara prosedural keluarga harus terlibat.

Keluarga yang menolak biasanya terjadi pada pasien yang beberapa kali dirawat dengan masalah yang sama. Dan keluarga memiliki tanggung jawab lain yang harus dilakukan di rumah atau karena pekerjaan. 5) Percobaan bunuh diri yang berulang sering terjadi ketika pasien sudah berpindah ke ruang yang lebih tenang. Karena pengawasan yang kurang intensif, dan lingkungan yang kurang nyaman untuk pasien. Sehingga pasien harus kembali lagi dirawat di ruang UPIP.

\section{SIMPULAN}

Terjadi peningkatan kasus risiko bunuh diri pada pasien yang di rawat di ruang perawatan intensif psikiatri, berkisar 30-50\% dalam satu tahun terakhir. Didapatkan lima tema yang didapatkan dari pengalaman perawat dalam merawat pasien dengan risiko bunuh diri, yaitu penemuan kasus, perlindungan keselamatan pasien, motivasi yang diberikan perawat, upaya melibatkan keluarga dalam perawatan, serta kendala yang hadapi perawat dalam merawat pasien dengan risiko bunuh diri. 


\section{DAFTAR PUSTAKA}

Fleischmann A (2016). Suicide an Unnecessary : Death Suicide in the world. Secon Edition. United Kingdom : Oxford University Press.

Fortaine, K.L.(2009). Mental health nursing. $\left(6^{\text {th }}\right.$ ed.).New Jersey: Pearson Education,Inc

Gomez-Duran, E.L, et al. (2012). Clinical and Epidemiological Aspects of Suicide in Patients with Schizoprenia. ActasEspPsiquiatr 2012;40(6):333-45.

Mann, J.J., Apter, A., Bertolote, J.,et al. (2010). Suicide Prevention Strategies: A Systemic Review. JAMA Johns Hopkins University on May 14.

Scott, A \&Guo, B. (2012). For which Strategies of Suicide Prevention is There Evidence of Effectiveness?. The Regional Office for Europe ofWHO: ISSN 2227-4316.

Stevens, M., Bond, L., Roberts, HM., Platt, S. (2008). Prevention of Suicide and Suicidal Behaviour in Adolescents (Protocol). The Cochrane Collaboration and Published, Issue 3.Publised by John Wiley \& Sons, Ltd.Diakses 18Februari 2015 dari The Cochrane Library.

Stuart, G.W.(2009). Principles and practice of psychiatric nursing. $9^{\text {th }}$ ed. Mosby.Inc.

- (2016). Keperawatan Kesehatan Jiwa Stuart. Edisi bahasa Indonesia. Singapore : Elsiever.

Wassermann D, et al (2016). Suicide an Unnecessary Death. United Kingdom : Oxford University Press.

Wood. S, Bellis. M.A, Mathieson. J, Foster. K. (2010). Self Harm and Suicide: A Review of Evidence for Preventionfrom The UK Focal Point for Violence and Injury Prevention. Liverpool John Moores University, Liverpool UK. www.cph.org.uk. 